\title{
Temporal Variations in Phytoplankton Assemblages at Dol Net Fishing Grounds of Major Tidal Creeks of Maharashtra, India
}

\author{
R. Ratheesh Kumar ${ }^{1 *}$, A.P. Dineshbabu ${ }^{1}$, A.K. Jaiswar ${ }^{2}$, S.P. Shukla ${ }^{2}$, \\ N. Manju Lekshmi ${ }^{3}$, G.B. Sreekanth ${ }^{4}$, A.D. Nakhawa ${ }^{1}$ and V.V. Singh ${ }^{1}$ \\ ${ }^{1}$ ICAR-Central Marine Fisheries Research Institute, Mumbai- 682 018, India \\ ${ }^{2}$ ICAR - Central Institute of Fisheries Education, Mumbai - 400061, India \\ ${ }^{3}$ ICAR - Central Institute of Fisheries Technology, Kochi - 682029, India \\ ${ }^{4}$ ICAR - Central Coastal Agricultural Research Institute, Goa - 403402, India \\ *Corresponding author
}

\section{A B S T R A C T}

\begin{tabular}{|c|}
\hline Keywords \\
\hline $\begin{array}{l}\text { Biodiversity indices, } \\
\text { North eastern Arabian } \\
\text { Sea, Phytoplankton, } \\
\text { Physico-chemical } \\
\text { parameters, Seasonal } \\
\text { variation, Tidal creeks }\end{array}$ \\
\hline Article Info \\
\hline $\begin{array}{l}\text { Accepted: } \\
\text { 04 May } 2018 \\
\text { Available Online: } \\
\text { 10 June } 2018\end{array}$ \\
\hline
\end{tabular}

Phytoplankton dynamics plays a vital role in determining the productivity of any coastal ecosystem. In this study, temporal variability in phytoplankton composition and diversity was assessed with respect to the physico-chemical parameters of water in major dol net fishing grounds of two spatially adjacent tidal creeks (Thane and Vasai) of Maharashtra. The phytoplankters identified belonged to 84 and 69 species in Thane and Vasai creeks, respectively. Numerical abundance of phytoplankton ranged from $8.7 \times 10^{4}$ cells $\mathrm{L}^{-1}$ to $4.3 \times 10^{5}$ cells $\mathrm{L}^{-1}$. Diatoms were the major group in both the creeks followed by dinoflagellates. Plankton density, diversity, evenness and richness were significantly higher in winter monsoon season. Phytoplankton density is positively correlated with phosphate, nitrate, nitrite, chlorophyll-a, diatoms and dinoflagellates, and negatively correlated with total suspended solids and silicates. Canonical correspondence analysis established that temperature, salinity and nutrients regulate the temporal patterns in phytoplankton composition. This study has provided fruitful insights on the diversity, abundance and temporal variations of phytoplankton assemblages under the influence of physico-chemical parameters of water in the tidal creeks of Maharashtra.

\section{Introduction}

Tidal creeks are funnel-shaped dynamic coastal ecosystems affected by ebbing and flooding of ocean tides and characterised by continuous flushing, mixing and replenishment of nutrients (Dalrymple, 1992; Semeniuk, 1996). Moreover, these habitats support unique flora and fauna, including migrants and residents of various aquatic species (Sreekanth et al., 2016). In Maharashtra, 48 tidal creeks have been reported (Vikas et al., 2015) and most of these creeks are rich in fish diversity and abundance which support the traditional dol net fishery. Dol nets are location-specific stationary bag nets extensively used in the tidal creeks of Maharashtra to harvest fish. Fish production in the coastal ecosystem is believed to be influenced by the variations in phytoplankton 
community structure, primary production and hydrographic parameters (Roy et al., 2010; Thomas et al., 2016). Phytoplankton is the base trophic level in the marine food web and remains as the major source of energy flow to higher trophic levels in coastal ecosystems (Tiwari and Chauhan, 2006; Saifullah et al., 2014).

The spatio-temporal variability in distribution and abundance of the phytoplankton community in coastal ecosystems is regulated by a number of physico-chemical factors (Hulyal and Kaliwal, 2009; Gabriel et al., 2013).

The effects of seasonality in the coastal waters such as creeks and estuaries are very strong and show substantial influence on phytoplankton production and food-web dynamics (Devassy and Goes, 1988). This variability of phytoplankton, in turn, affects the diversity and abundance of other aquatic fauna including fish (Alheit et al., 2005). Therefore, the community composition, biomass and temporal variations of phytoplankton need to be understood to delineate the fish production dynamics of the coastal ecosystem. Nevertheless, in the tidalcreek ecosystems, studies pertaining to phytoplankton communities in terms of diversity, composition and abundance with special reference to fishing grounds are limited.

In this study, the dynamics of phytoplankton were analysed with respect to the physicochemical parameters of water in the major $d o l$ net fishing grounds of two spatially adjacent tidal creeks (Thane and Vasai) of Maharashtra. The major objectives of this study were to analyse the temporal patterns in diversity and abundance of phytoplankton communities and to elucidate the effect of the physico-chemical parameters of water on the dynamics of phytoplankton.

\section{Materials and Methods}

\section{Study area}

Thane and Vasai creeks of Maharashtra are two major tidal creeks in the shoreline of the north eastern Arabian Sea. Both the creeks are spatially adjacent and fed partially by Ulhas River. At Thane, Ulhas River splits into two branches, one flows to the west and merges with the Vasai Creek and the other flows to the south and merges with the Thane Creek. The sampling stations with an average depth of $5 \mathrm{~m}$ were selected along the lower stretch of both the creeks. Stations selected in Thane and Vasai creeks are indicated as Mahul station $\left(72^{\circ} 51^{\prime} 40.65^{\prime}\right.$ ' E, $18^{\circ} 52^{\prime} 39.08^{\prime}$ 'N) and Naigaon station $\left(72^{\circ} 45^{\prime} 19.18^{\prime}\right.$ 'E, $19^{\circ} 29^{\prime}$ $21.31^{\prime \prime} \mathrm{N}$ ) respectively, due to the proximity to Mahul and Naigaon fishing villages. These stations represent the major dol net fishing grounds in the selected creeks (Fig.1). Sampling was carried out on a monthly basis from December 2015 to November 2017. In order to minimize the possible effects of tidal variations and environmental conditions, both the stations were sampled during high tide with similar tidal characteristics in the morning hours. The data collected were pooled into four pre-determined seasons; winter monsoon (December to February), spring inter-monsoon (March to May), summer monsoon (June to September) and fall inter-monsoon (October -November) as per Chatterjee et al., (2012).

\section{Estimation of phytoplankton and chlorophyll-a}

The samples were collected and concentrated to $50 \mathrm{~mL}$ by filtering $50 \mathrm{~L}$ of water through plankton net $(30 \mu \mathrm{m}$ mesh size). The phytoplankton samples were preserved in $0.4 \%$ Lugol's solution for further qualitative and quantitative analyses. Identification and quantification were carried out following the 
standard literature and methodologies (Welch, 1948; Subhramanyan, 1959). The individual species were counted using a Sedgwick-Rafter counting cell and the numbers are expressed as cells $\mathrm{L}^{-1}$ (Welch, 1948). For the estimation of chlorophyll-a, water samples were concentrated using a cellulose acetate-based filter assembly of $0.45 \mu \mathrm{m}$ pore size. The pigments were extracted from the plankton concentrate with aqueous acetone and the optical densities of the extracts were determined spectrophotometrically following the guidelines of APHA (2005). The results are expressed in $\mathrm{mg} \mathrm{m}^{-3}$.

\section{Estimation of physico-chemical parameters of water}

The physico-chemical parameters such as temperature $\left({ }^{\circ} \mathrm{C}\right)$, salinity $(\%), \quad \mathrm{pH}$ and turbidity (NTU) of water were recorded onsite using a mercury-in-glass thermometer, a refractometer (ERMA, Tokyo), digital $\mathrm{pH}$ meter (Hanna Instruments, India) and nephelometer (Eutech Instruments, Singapore), respectively. For the estimations of dissolved oxygen (DO in $\mathrm{mg} \mathrm{L}^{-1}$ ), biochemical oxygen demand (BOD5 in $\mathrm{mg}$ $\left.\mathrm{L}^{-1}\right)$, ammonia- $\mathrm{N}\left(\mu \mathrm{M} \mathrm{L}^{-1}\right)$, nitrate- $\mathrm{N}\left(\mu \mathrm{M} \mathrm{L}^{-1}\right)$, nitrite- $\mathrm{N}\left(\mu \mathrm{M} \mathrm{L} \mathrm{L}^{-1}\right)$, orthophosphate $\left(\mu \mathrm{M} \mathrm{L}^{-1}\right)$, silicate $\left(\mu \mathrm{M} \mathrm{L}^{-1}\right)$ and total suspended solids (TSS in $\mathrm{mg} \mathrm{L}^{-1}$ ) the standard methodologies described in APHA (2005) guidelines were used.

\section{Data analysis}

The diversity indices for phytoplankton such as Shannon-Wiener diversity index ( $\left.\mathrm{H}^{\prime}\right)$, Margalef's richness index (d) and Heip's evenness index (E) were estimated using PAST software (Hammer et al., 2001). Mean values with standard error were calculated for physico-chemical parameters and the diversity indices of phytoplankton were determined using the PROC MEANS procedure of SAS
(SAS Institute, 2016). To compare the phytoplankton communities, they were classified into groups such as diatoms, dinoflagellates, green algae and blue-green algae on the basis of standard taxonomic classification (Subhramanyan, 1959). Pearson's correlation coefficients were calculated for phytoplankton groups with physico-chemical parameters of water using PROC CORR procedure of SAS (SAS Institute, 2016). To visualise the spatiotemporal variations in phytoplankton species assemblages and their relationship with the environmental variables, the data were subjected to canonical correspondence analysis (CCA) using PAST software (Hammer et al., 2001).

\section{Results and Discussion}

\section{Phytoplankton composition}

The phytoplankton species identified were 84 (42 families) and 69 (33 families) at Mahul and Naigaon stations, respectively. Among these, diatom was the major group in terms of abundance and diversity at both the stations. At Mahul, 55 species of diatoms comprising Bacillariophyceae (24), Mediophyceae (19) and Coscinodiscophyceae (12) were identified (Table 1). Forty-seven species of diatoms comprising Bacillariophyceae (20), Mediophyceae (16) and Coscinodiscophyceae (11) were collected at Naigaon. Navicula, Pleurosigma, Nitzschia, Bacteriastrum, Biddulphia, Chaetoceros, Coscinodiscus, Triceratium, Thalassiothrix, Skeletonema, Fragilaria and Fragilariopsis were the major genera under Bacillariophyceae while Dinophysis, Prorocentrum, Peridinium, Protoperidinium, Gymnodinium, Ceratium and Phyrocystis were the dominant genera under Dinophyceae. The major genera under Chlorophyceae included Ankistrodesmus, Pediastrum, Closterium, Scenedemus and Zygnema, and Trichodesmium, Microcystis 
and Oscillatoria were the major representatives of Cyanophyceae. Phytoplankters identified during the sampling period in Naigaon and Mahul stations with their range in the number of cells $\mathrm{L}^{-1}$ are presented in Table 2.

Similar to our results at the north-eastern Arabian Sea region, a total of 103 species of phytoplankters were recorded in the creek waters of western mangrove of Kachchh region (Gujarat) with 82 species of diatoms, 16 species of dinoflagellates, 3 species of blue-green algae and 2 species of green algae by Saravanakumar et al., (2008). The present study indicates that the diatoms constitute the major proportion of phytoplankton community in coastal ecosystems which was supported with the earlier reports from similar ecosystems (Kadam and Tiwari, 2011; Temkar et al., 2015). In the present study, to the total plankton density diatoms contributed $77 \%$ (based on cells $\mathrm{L}^{-1}$ ), followed by dinoflagellates $13 \%$, blue-green algae $6 \%$ and green algae $4 \%$ of the total phytoplankton density. In the creek waters of Kachchh-, $79.6 \%$ diatoms, $15.5 \%$ dinoflagellates, $2.9 \%$ blue-green algae and $1.9 \%$ green algae contributed to the abundance of phytoplankton as reported by Saravanakumar et al., (2008). In coastal waters, phytoplankton community is dominated by diatoms on account of the availability of optimal quantities of solar radiation and nutrients which intensifies their multiplication and growth rates (Stowe, 1996). Temporal variations were observed in percentage contribution of phytoplankton groups with the dominance of green algae in summer monsoon, diatoms in winter monsoon and blue-green algae in spring inter-monsoon at both the stations (Fig. 3). In this study, dinoflagellates did not show any seasonality in abundance. The low density of phytoplankton in the summer monsoon observed in this study may be due to the increased precipitation, runoff and subsequent reduction in the salinity of water along the coastal waters (Mitbavkar and Anil, 2008).

\section{Phytoplankton density}

Phytoplankton density was significantly higher at Naigaon station compared to Mahul. The phytoplankton density at Mahul station ranged from $8.7 \times 10^{4}$ cells $\mathrm{L}^{-1}$ to $2.4 \times 10^{5}$ cells $\mathrm{L}^{-1}$ whereas, at Naigaon, it ranged from $1.2 \times 10^{5}$ cells L -1 to $4.3 \times 10^{5}$ cells $\mathrm{L}^{-1}$ (Fig. 2 ). Plankton production in the study area during different seasons was in a moderate range. While comparing the seasonal patterns in plankton density, winter monsoon recorded the highest values and the lowest ones were observed during summer monsoon (Fig. 2). A comparatively higher range of phytoplankton density $\left(2.4 \times 10^{5}\right.$ cells $\mathrm{L}^{-1}$ to $9.41 \times 10^{6}$ cells $\left.\mathrm{L}^{-1}\right)$ was observed in the creek waters of Kachchh (Saravanakumar et al., 2008). Temkar et al., (2015) reported higher levels of phytoplankton density and diversity in the winter season and low density in summer along the coastal waters of Veraval, Gujarat. In this study, the concentrations of inorganic nutrients like nitrate, nitrite and phosphate were found to be high during winter monsoon at both the stations. The high diversity and density of phytoplankton during winter monsoon could be attributed to the favourable environment and abundance of limiting nutrients in comparison with the other seasons.

\section{Diversity pattern}

There was a significant difference in the diversity of phytoplankters between stations and the values were high in Mahul in comparison with Naigaon during all the seasons. While comparing the seasonal patterns, the diversity was the highest during winter monsoon and the lowest values were recorded during summer monsoon to both the stations. The general pattern in diversity indices was comparable with the profile of 
Shannon diversity (2-3) in coastal ecosystems (Magurran, 2004). Shannon index will be the highest in situations where the ecosystem is least disturbed (Jitendra et al., 2015). This corroborates the results of this study, where the values were highest during winter monsoon with low current speed and turbidity, low levels of suspended solids, etc. The abundance of limiting nutrients compared to other seasons and low environmental disturbance may be the reason for the high diversity and evenness of phytoplankters during winter monsoon season at both the stations. At the same time, the diversity gets decreased when the ecosystem is turbulent or under perturbed conditions (monsoon). Summer monsoon on the west coast creates disturbance in the coastal environment with high wind and current speeds, high rainfall and runoff, and drastic changes in the physicochemical parameters of water. Therefore, the lower levels of phytoplankton diversity will be noticed in these seasons complementing with the observations of the current study.

\section{Chlorophyll - a}

Chlorophyll-a (Chl-a) is the active photosynthetic pigment of phytoplankton that regulates the primary production in coastal ecosystems (Yeragi and Yeragi, 2003). The concentration of $\mathrm{Chl}-\mathrm{a}$ in this study ranged from $2.66 \mathrm{mg} \mathrm{m}^{-3}$ to $5.53 \mathrm{mg} \mathrm{m}^{-3}$ in Mahul Creek and from $3.54 \mathrm{mg} \mathrm{m}^{-3}$ to $6.24 \mathrm{mg} \mathrm{m}^{-3}$ in Naigaon Creek. Harnstorm et al., (2009) have reported the $\mathrm{Chl}-\mathrm{a}$ concentrations ranging from $1.67 \mathrm{mg} \mathrm{m}^{-3}$ to $4.87 \mathrm{mg} \mathrm{m}^{-3}$ in a tidal creek of Mangalore. In this study, a moderate concentration of chlorophyll was obtained in comparison with the earlier reports. The highest concentration of Chl-a was noticed during winter monsoon and the lowest in summer monsoon. This observation is in correspondence with the variation in phytoplankton density as at both the stations, the values of Chl-a and phytoplankton density were highest during winter monsoon. This seasonal profile of phytoplankton and Chl-a was in alliance with the recent studies in coastal ecosystems (Vase et al., 2018). During summer monsoon, the dilution of seawater occurs with the freshwater influx and huge quantities of suspended solids are released into the ecosystem. This generally reduces the incidence of solar radiation that catalyses primary production. This could be a plausible explanation for the decrease in Chl-a concentration during summer monsoon (Rajasekar et al., 2010).

\section{Temporal variations and interactions of physico-chemical parameters}

There were significant differences in physicochemical parameters between seasons and stations. Temperature, salinity and $\mathrm{pH}$ were recorded high during spring inter-monsoon and low during summer monsoon at both the stations. This can be considered as a result of the incidence of the high amount of solar radiation during summer (spring intermonsoon) and therefore, an increase in temperature is expected during this season. The high degree of evaporation due to high temperature could be the reason for high salinity during spring inter-monsoon (Arthur, 1972). $\mathrm{pH}$ was found to be in the alkaline range ( 7.3 to 8.2 ) throughout the study period at both the stations. Seasonal patterns in physico-chemical parameters were similar at both the stations. These observations were found to be in agreement with the reports from earlier studies (Sukumaran et al., 2013; Shahi et al., 2015). The high amount of rainfall, consequent runoffs and dilution of the creek water during summer monsoon might have reduced the temperature, salinity and $\mathrm{pH}$ in that season.

DO was highest during summer monsoon and lowest during spring inter-monsoon at both the stations. Research reports from earlier 
attempts show that low salinity and low temperature could be the reason for higher solubility of oxygen in water (Levinton, 2001; Saravanakumar et al., 2008; Puthiya et al., 2009). In this study, low values of DO were observed in correspondence with high temperature and high salinity levels.

The Pearson correlation analysis has also shown a significant negative correlation of DO with salinity and temperature. Comparatively higher value of BOD noted at Naigaon station than Mahul indicates higher consumption of oxygen and higher organic pollution. This higher organic pollution might be the reason for low phytoplankton diversity and richness at Naigaon compared to Mahul. In this study, a significant negative correlation was observed between BOD and DO in both the stations. An increase in BOD causes a reduction in dissolved oxygen concentration in coastal ecosystems. The high BOD values indicate organic pollution and thus, a higher consumption of oxygen by microbes for decomposing the organic compounds (Lekshmi et al., 2018).

Fig.1 Map showing the sampling locations

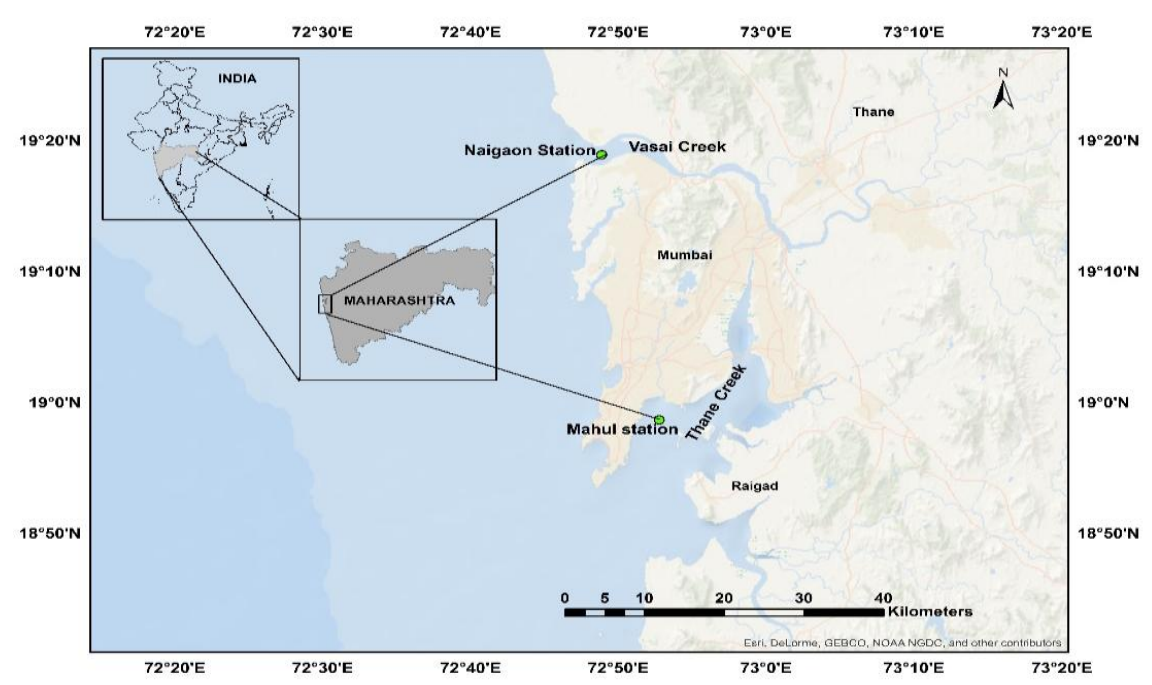

Fig.2 Spatio-temporal variation in phytoplankton density

600000

500000

400000

300000

200000

100000

0

$\begin{array}{lll}\text { WM SI } & \text { Seasons SM } \\ \text { Naigoan } & \end{array}$


Fig.3 Spatio-temporal variations in percentage composition of phytoplankton

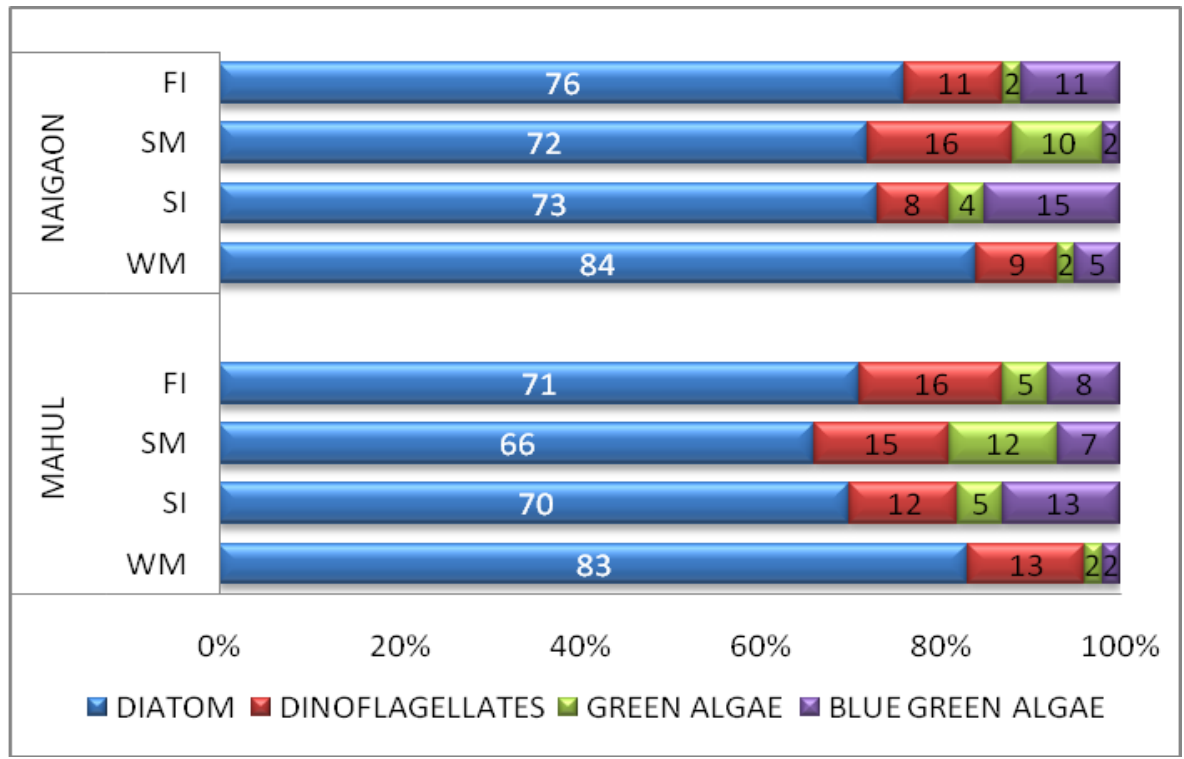

Fig.4 CCA plot for physico-chemical variables, plankton group and seasons

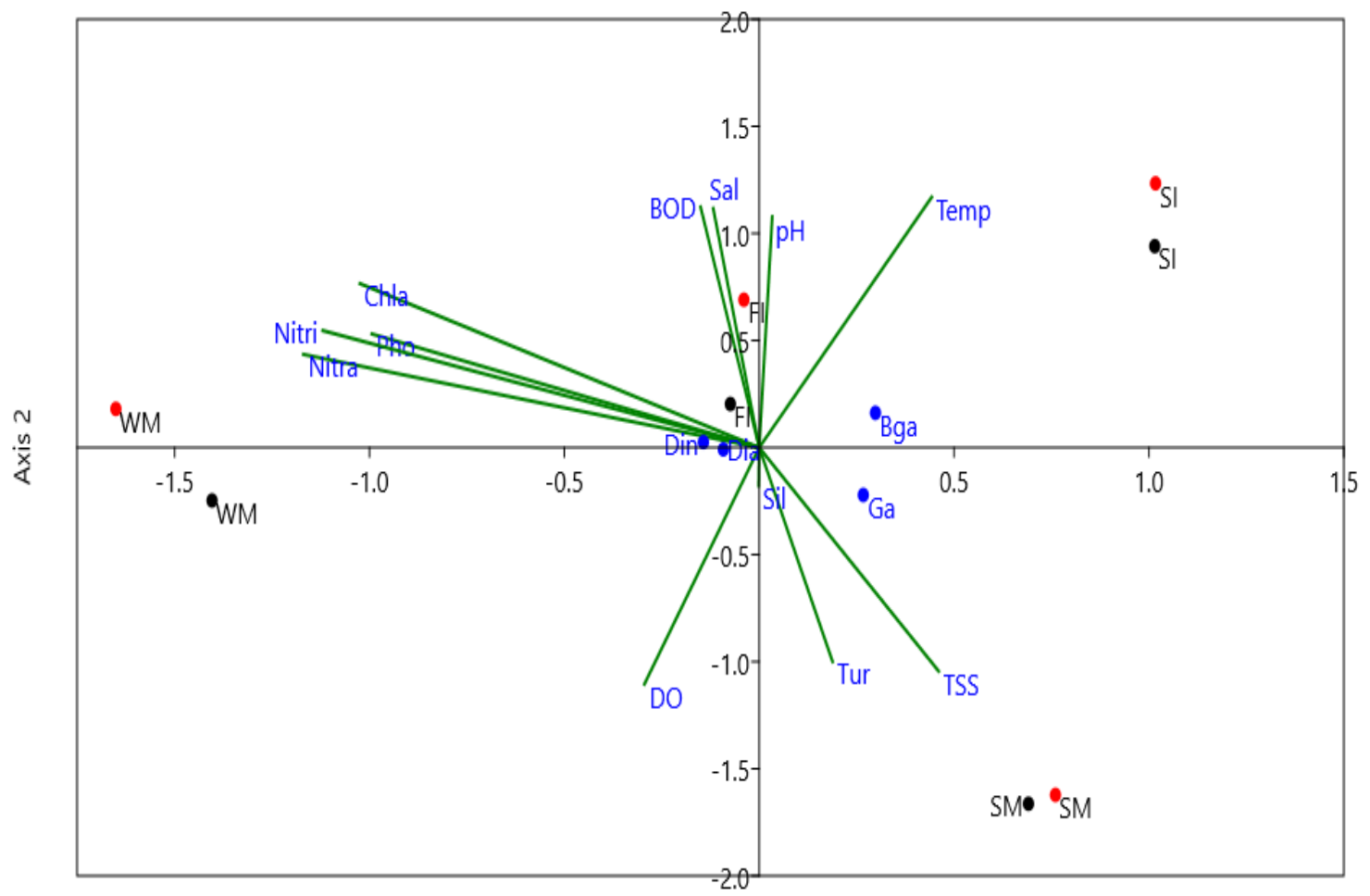

Axis 1 
Table.1 Phytoplankton groups observed from the dolnet fishing grounds of Vasai and Thane creek

\begin{tabular}{|c|c|c|c|c|c|c|c|}
\hline \multicolumn{4}{|c|}{ Mahul (Thane creek) } & \multicolumn{4}{|c|}{ Naigoan (Vasai creek) } \\
\hline Groups & Class & No.families & Species & Groups & Class & No.families & Species \\
\hline \multirow[t]{3}{*}{ Diatoms } & Bacillariophyceae & 9 & 24 & Diatoms & Bacillariophyceae & 7 & 20 \\
\hline & Mediophyceae & 8 & 19 & & Mediophyceae & 8 & 16 \\
\hline & Coscinodiscophyceae & 5 & 12 & & Coscinodiscophyceae & 4 & 11 \\
\hline Dinoflagellates & Dinophyceae & 8 & 14 & Dinoflagellates & Dinophyceae & 7 & 12 \\
\hline \multirow[t]{3}{*}{ Green algae } & Chlorophyceae & 5 & 6 & Green algae & Chlorophyceae & 4 & 6 \\
\hline & Zygnematophyceae & 1 & 2 & & Zygnematophyceae & 0 & 0 \\
\hline & Ulvophyceae & 1 & 1 & Blue-green algae & Cyanophyceae & 3 & 4 \\
\hline Blue-green algae & Cyanophyceae & 5 & 6 & & & & \\
\hline Total & & 42 & 84 & Total & & 33 & 69 \\
\hline
\end{tabular}

Table.2 Phytoplankton taxa identified and its range $\left(\right.$ Cells $\left.\mathrm{L}^{-1}\right)$

\begin{tabular}{|l|l|l|l|}
\hline Family & Phytoplankton Species & Range (Cells L-1) \\
\hline & Diatoms & Mahul & Naigoan \\
\hline Amphipleuraceae & Amphiprora sp. & $0-1500$ & $0-2200$ \\
\hline Naviculaceae & Naviculatransitans & $0-14590$ & $0-10200$ \\
\hline Naviculaceae & Naviculalongissima & $0-6900$ & $0-17900$ \\
\hline Naviculaceae & Naviculadistans & $0-5400$ & $0-16700$ \\
\hline Pinnulariaceae & Pinnulariarectangulata & $0-3700$ & Nil \\
\hline Plerosigmataceae & Pleurosigmaangulatum & $0-11300$ & $0-23200$ \\
\hline Plerosigmataceae & Pleurosigmanormanii & $0-22600$ & $0-31400$ \\
\hline Plerosigmataceae & Pleurosigmaelongatum & $0-10100$ & Nil \\
\hline Naviculaceae & Gyrosigmabalticum & $0-2100$ & $0-21650$ \\
\hline Bacillariaceae & Pseudonitzschiaseriata & $0-16700$ & $0-16700$ \\
\hline Bacillariaceae & Nitzschiaclosterium & $0-2300$ & $0-11000$ \\
\hline Bacillariaceae & Nitzschaiseriata & $0-36000$ & $0-62500$ \\
\hline Bacillariaceae & Nitzschiapungens & $0-6000$ & $0-9450$ \\
\hline Bacillariaceae & Nitzschialongisima & $0-14200$ & Nil \\
\hline Bacillariaceae & Nitzschiaangularis & $0-6340$ & $0-13400$ \\
\hline Bacillariaceae & Nitzschia sigma & $0-2865$ & Nil \\
\hline Thalassionemataceae & Thalasionemanitzschioides & $0-12600$ & $0-5800$ \\
\hline Thalassionemataceae & Thalassiothrixfrauenfeldii & $0-1350$ & $0-6200$ \\
\hline Surirellaceae & Surirellafluminensis & $0-7500$ & $0-12450$ \\
\hline Catenulaceae & Amphora sp & $0-22000$ & $0-25000$ \\
\hline Thalassionemataceae & Thallassiothrixlongissima & $0-680$ & $0-19670$ \\
\hline Bacillariaceae & Fragilariopsissp & $0-5400$ & $400-32500$ \\
\hline Fragilariaceae & Fragilariaoceanica & $0-23300$ & $0-14300$ \\
\hline Fragilariaceae & Synedraformosa & $0-18000$ & $0-7700$ \\
\hline Biddulphiaceae & Biddulphiasinensis & $0-1340$ & $0-9650$ \\
\hline Streptothecaceae & Streptothecasp & $0-22200$ & $0-19200$ \\
\hline Biddulphiaceae & Biddulphiamobilensis & $0-4600$ & $0-6600$ \\
\hline Biddulphiaceae & Biddulphiapulchina & $0-7100$ & $0-15800$ \\
\hline & & & \\
\hline
\end{tabular}




\begin{tabular}{|c|c|c|c|}
\hline Leptocylindraceae & Leptocylindrusdanicus & $0-2300$ & $0-6430$ \\
\hline Chaetocerotaceae & Bacteriastrumhyalinum & $0-2300$ & $0-9800$ \\
\hline Chaetocerotaceae & Bacteriastrumdelicatum & $0-2300$ & Nil \\
\hline Chaetocerotaceae & Chaetocerostortissimus & $0-21500$ & $0-13700$ \\
\hline Chaetocerotaceae & Chaetocerosaffinis & $0-1700$ & $0-23000$ \\
\hline Chaetocerotaceae & Chaetocerosbrevis & $0-9300$ & $0-7300$ \\
\hline Chaetocerotaceae & Chaetoceroscurvisetus & $0-10300$ & $400-28700$ \\
\hline Chaetocerotaceae & Chaetocerosdiversus & $0-2300$ & $0-3400$ \\
\hline Thalassiosiraceae & Thalassiosirasubtilis & $0-1550$ & $0-12500$ \\
\hline Thalassiosiraceae & Thalassiosiraeccentrica & $0-5600$ & Nil \\
\hline Thalassiosiraceae & Planktoniellaspp & $0-6200$ & $0-14600$ \\
\hline Skeletonemataceae & Skeletonema sp. & $0-16200$ & $1350-39800$ \\
\hline Stephanodiscaceae & Cyclotellastriata & $0-11700$ & $0-1600$ \\
\hline Lithodesmiaceae & Ditylumbrightwellii & $0-3350$ & $0-6350$ \\
\hline Biddulphiaceae & Biddulphiabiddulphiana & $0-780$ & Nil \\
\hline Hemidiscaceae & Hemidiscussp & $0-2300$ & Nil \\
\hline Coscinodiscaceae & Coscinodiscusgranii & $0-3500$ & $2400-30200$ \\
\hline Rhizosoleniaceae & Guinardiasp & $0-1800$ & $0-6700$ \\
\hline Rhizosolenaceae & Rhizosoleniaserieta & $0-3000$ & $0-8670$ \\
\hline Rhizosolenaceae & Rhizosoleniasetigera & $0-6500$ & $0-12300$ \\
\hline Rhizosoleniaceae & Rhizosoleniastolterfothii & $0-1550$ & $0-8050$ \\
\hline Triceratiaceae & Triceratiumdubium & $0-16350$ & $0-12400$ \\
\hline Triceratiaceae & Triceratiumreticulatum & $0-9400$ & $0-13100$ \\
\hline Triceratiaceae & Triceratiumalternans & $0-1220$ & $0-7300$ \\
\hline Melosiraceae & Melosirasp & $0-7560$ & $340-9560$ \\
\hline Melosiraceae & Melosiraundulata & $0-5600$ & $0-13600$ \\
\hline Coscinodiscaceae & Coscinodiscuslorenzianus & $0-7600$ & $0-3200$ \\
\hline \multicolumn{4}{|c|}{ Dinoflagellates } \\
\hline Dinophyceae & Dinophysistripos & $0-24500$ & $0-15400$ \\
\hline Dinophyceae & Dinophysisbicaudata & $0-9700$ & $0-9700$ \\
\hline Dinophysaceae & Dinophysiscaudata & $0-4400$ & $0-5000$ \\
\hline Prorocentraceae & Prorocentrum lima & $0-1540$ & $0-12400$ \\
\hline Prorocentraceae & Prorocentrummicans & $0-5800$ & Nil \\
\hline Peridiniaceae & Peridiniumsp & $0-7700$ & $0-9440$ \\
\hline Peridiniaceae & Peridiniumbiconicum & $0-400$ & $0-4300$ \\
\hline Protoperidiniaceae & Protoperidiniumspp & $0-16500$ & Nil \\
\hline Pyrocystaceae & Pyrocystisfusiformis & $0-4500$ & $0-12300$ \\
\hline Ceratiaceae & Ceratiumfurca & $0-5400$ & $0-12500$ \\
\hline Pyrophacaceae & Pyrophacushorologium & $0-5020$ & $0-5020$ \\
\hline Ceratiaceae & Ceratiumlineatum & $0-25400$ & $0-6500$ \\
\hline Gymnodiniaceae & Gymnodiniumsp & $0-6400$ & $0-11680$ \\
\hline Gonyaulacaceae & Gonyaulaxspinifera & $0-3200$ & $0-7400$ \\
\hline \multicolumn{4}{|c|}{ Green algae } \\
\hline Selenestraceae & Ankistodesmussp & $0-2700$ & $0-5467$ \\
\hline Hydrodictyaceae & Pediastrumsp & $0-4300$ & $0-3300$ \\
\hline Chlorellaceae & Actinastrumsp & $0-4000$ & $0-4210$ \\
\hline
\end{tabular}


Int.J.Curr.Microbiol.App.Sci (2018) 7(6): 465-480

\begin{tabular}{|l|l|l|l|}
\hline Scenedesmaceae & Scenedesmussp & $0-7120$ & $0-3000$ \\
\hline Zygnematacae & Zygnemasp & $0-3500$ & $0-6600$ \\
\hline Ulotrichaceae & Ulothrixsp & $0-6450$ & Nil \\
\hline Selenastraceae & Ankistrodesmussp & $0-3400$ & $0-11400$ \\
\hline Dunaliellaceae & Dunaliellasalina & $0-3200$ & Nil \\
\hline Closteriaceae & Closteriumsp & Blue-green algae \\
\hline \multicolumn{3}{|c|}{$0-12370$} & Nil \\
\hline Microcoleaceae & Trichodesmiumerythraeum & $0-9670$ & $0-32340$ \\
\hline Microcystaceae & Microcystissp & $0-300$ & $0-13210$ \\
\hline Oscillatoriaceae & Oscillatoriasp & $0-3200$ & $0-29650$ \\
\hline Chroococcaceae & Chrococcussp & $0-3250$ & $0-3200$ \\
\hline Merismopediaceae & MerismopediaSp & $0-9700$ & Nil \\
\hline Nostocaceae & Anabaena $s p$ & $0-4400$ & Nil \\
\hline
\end{tabular}

Table.3 Mean \pm standard error values of physico-chemical parameters and plankton diversity indices between seasons

\begin{tabular}{|c|c|c|c|c|c|c|c|c|}
\hline \multirow[b]{2}{*}{ Parameter } & \multicolumn{4}{|c|}{ Mahul } & \multicolumn{4}{|c|}{ Naigoan } \\
\hline & WM & SI & SM & FI & WM & SI & SM & FI \\
\hline Temperature & $26.82 \pm 0.10$ & $29.87 \pm 0.233$ & $25.5 \pm 0.13$ & $27.5 \pm 0.25$ & $27.16 \pm 0.089$ & $30.13 \pm 0.29$ & $26.16 \pm 0.225$ & $27.75 \pm 0.45$ \\
\hline Salinity & $31.15 \pm 0.311$ & $33.13 \pm 0.218$ & $25.42 \pm 0.72$ & $28.82 \pm 1.17$ & $30.78 \pm 0.926$ & $32.22 \pm 0.67$ & $24.82 \pm 0.74$ & $28.36 \pm 0.2$ \\
\hline $\mathrm{pH}$ & $7.9 \pm 0.05$ & $8.2 \pm 0.058$ & $7.42 \pm 0.09$ & $7.76 \pm 0.1$ & $7.87 \pm 0.033$ & $8.1 \pm 0.03$ & $7.35 \pm 0.087$ & $7.6 \pm 0.1$ \\
\hline DO & $5.66 \pm 0.13$ & $4.22 \pm 0.055$ & $5.86 \pm 0.20$ & $5.41 \pm 0.4$ & $4.59 \pm 0.50$ & $3.91 \pm 0.23$ & $5.51 \pm 0.10$ & $4.46 \pm 0.09$ \\
\hline BOD & $2.6 \pm 0.09$ & $2.92 \pm 0.058$ & $1.68 \pm 0.13$ & $2.3 \pm 0.2$ & $2.93 \pm 0.145$ & $3.37 \pm 0.25$ & $2.02 \pm 0.07$ & $2.45 \pm 0.25$ \\
\hline Chl-a & $5.53 \pm 0.28$ & $4.22 \pm 0.09$ & $2.66 \pm 0.21$ & $4.76 \pm 0.25$ & $6.24 \pm 0.368$ & $4.6 \pm 0.27$ & $3.54 \pm 0.29$ & $5.14 \pm 0.14$ \\
\hline Turbidity & $48.13 \pm 8.03$ & $38.31 \pm 2.35$ & $70.89 \pm 3.95$ & $58.55 \pm 9.15$ & $55.63 \pm 8.87$ & $46.44 \pm 7.87$ & $87.93 \pm 7.38$ & $67.55 \pm 6.39$ \\
\hline TSS & $64.39 \pm 12.97$ & $59.70 \pm 4.07$ & $124.7 \pm 21.62$ & $74.45 \pm 6.75$ & $76.12 \pm 2.66$ & $75.03 \pm 10.29$ & $167.2 \pm 15.13$ & $94.45 \pm 46.75$ \\
\hline Phosphate & $4.25 \pm 0.28$ & $1.67 \pm 0.17$ & $1.39 \pm 0.097$ & $3.66 \pm 0.39$ & $6.97 \pm 1.48$ & $3.89 \pm 0.45$ & $1.89 \pm 0.23$ & $5.99 \pm 0.32$ \\
\hline Nitrate & $19.40 \pm 2.12$ & $9.40 \pm 1.16$ & $7.18 \pm 0.83$ & $14.26 \pm 0.98$ & $28.4 \pm 7.25$ & $15.94 \pm 1.17$ & $10.78 \pm 2.58$ & $19.76 \pm 3.51$ \\
\hline Nitrite & $2.25 \pm 0.58$ & $0.92 \pm 0.062$ & $0.49 \pm 0.11$ & $1.24 \pm 0.09$ & $2.45 \pm 0.46$ & $1.12 \pm 0.189$ & $0.57 \pm 0.153$ & $2.19 \pm 0.25$ \\
\hline Silicate & $5.85 \pm 0.137$ & $4.82 \pm 0.31$ & $7.91 \pm 1.88$ & $14.31 \pm 0.62$ & $7.02 \pm 0.25$ & $7.15 \pm 1.75$ & $11.62 \pm 1.89$ & $17.32 \pm 0.62$ \\
\hline Ammonia & $0.46 \pm 0.054$ & $1.71 \pm 0.04$ & $0.19 \pm 0.05$ & $0.66 \pm 0.07$ & $0.92 \pm 0.20$ & $3.45 \pm 0.43$ & $0.37 \pm 0.06$ & $0.88 \pm 0.03$ \\
\hline $\begin{array}{l}\text { Plankton } \\
\text { density }\end{array}$ & $497.83 \pm 26.12$ & $337.18 \pm 9.33$ & $296.59 \pm 8.23$ & $391.5489 \pm 14.84$ & $656.54 \pm 50.05$ & $456.95 \pm 10.56$ & $349.17 \pm 16.21$ & $507.07 \pm 21.78$ \\
\hline Diatom & $456.23 \pm 22$ & $287.37 \pm 26.36$ & $242.07 \pm 9.5$ & $329.54 \pm 29$ & $604.48 \pm 55$ & $401.05 \pm 16$ & $304.98 \pm 16$ & $447.51 \pm 8$ \\
\hline Dinoflagellate & $170.36 \pm 3$ & $101.09 \pm 42.10$ & $108.70 \pm 21$ & $154.74 \pm 9$ & $195.95 \pm 55$ & $123.97 \pm 19$ & $134.06 \pm 16$ & $153.04 \pm 32$ \\
\hline Green algae & $53.26 \pm 6.1$ & $77.02 \pm 6.95$ & $92.94 \pm 14$ & $74.54 \pm 51$ & $42.33 \pm 12$ & $77.49 \pm 18$ & $93.89 \pm 11$ & $53.59 \pm 35$ \\
\hline $\begin{array}{ll}\text { Blue } & \text { green } \\
\text { algae } & \end{array}$ & $55.77 \pm 20$ & $108.55 \pm 11.86$ & $82.64 \pm 5.6$ & $103.24 \pm 20$ & $146.35 \pm 28$ & $162.37 \pm 48$ & $51.02 \pm 10$ & $142.84 \pm 33$ \\
\hline Dominance & $0.04 \pm 0.01$ & $0.06 \pm 0.002$ & $0.09 \pm 0.01$ & $0.058 \pm 0.01$ & $0.04 \pm 0.01$ & $0.051 \pm 0.01$ & $0.082 \pm 0.02$ & $0.06 \pm 0.01$ \\
\hline Diversity & $3.37 \pm 0.04$ & $3.2 \pm 0.001$ & $2.86 \pm 0.13$ & $3.2 \pm 0.04$ & $3.30 \pm 0.68$ & $3.22 \pm 0.05$ & $2.78 \pm 0.18$ & $3.17 \pm 0.30$ \\
\hline Evenness & $0.56 \pm 0.01$ & $0.516 \pm 0.017$ & $0.47 \pm 0.58$ & $0.52 \pm 0.03$ & $0.671 \pm 0.05$ & $0.65 \pm 0.53$ & $0.545 \pm 0.08$ & $0.53 \pm 0.03$ \\
\hline Margalef & $4.67 \pm 0.23$ & $4.13 \pm 0.15$ & $3.44 \pm 0.23$ & $4.41 \pm 0.05$ & $3.84 \pm 0.30$ & $3.05 \pm 0.18$ & $2.93 \pm 0.32$ & $3.55 \pm 0.16$ \\
\hline
\end{tabular}

Square root was taken for the plankton groups and dens 
Table.4 Correlation matrix of various physico-chemical parameters with plankton groups in Mahul

\begin{tabular}{|c|c|c|c|c|c|c|c|c|c|c|c|c|c|c|c|c|c|}
\hline & SST & $\mathrm{pH}$ & Sal & DO & BOD & Chl.a & Tur & TSS & Pho & Nitra & Nitri & Sil & $\mathrm{Am}$ & Pd & Dia & Dino & GA \\
\hline $\mathbf{P h}$ & $0.58^{*}$ & & & & & & & & & & & & & & & & \\
\hline Sal & 0.36 & $0.91 * *$ & & & & & & & & & & & & & & & \\
\hline$\overline{\text { DO }}$ & $-0.85^{* *}$ & $-0.74 * *$ & $-0.61 *$ & & & & & & & & & & & & & & \\
\hline BOD & $0.68^{*}$ & $0.87 * *$ & $0.81 * *$ & $-0.87 * *$ & & & & & & & & & & & & & \\
\hline Tur & $-0.87 * *$ & -0.35 & -0.17 & $0.66^{*}$ & -0.49 & 0.18 & & & & & & & & & & & \\
\hline TSS & -0.26 & $-0.83^{* *}$ & -0.91 ** & 0.48 & $-0.69 *$ & $-0.77^{* *}$ & 0.22 & & & & & & & & & & \\
\hline Pho & -0.55 & -0.30 & 0.05 & 0.49 & -0.28 & $0.56^{*}$ & 0.37 & -0.15 & & & & & & & & & \\
\hline Nitra & $-0.74 * *$ & -0.24 & 0.11 & 0.54 & -0.34 & $0.63^{*}$ & $0.70^{*}$ & -0.13 & $0.84^{* *}$ & & & & & & & & \\
\hline Nitri & $-0.74 * *$ & -0.16 & 0.13 & 0.47 & -0.31 & $0.61^{*}$ & $0.78^{* * *}$ & -0.08 & $0.66^{*}$ & $0.92 * *$ & & & & & & & \\
\hline Sil & -0.29 & $-0.78^{* *}$ & $-0.93^{* * *}$ & $0.57 *$ & $-0.79 * *$ & $-0.85^{* *}$ & 0.21 & $0.90^{* *}$ & -0.21 & -0.21 & -0.14 & & & & & & \\
\hline $\mathrm{Am}$ & $0.78^{* *}$ & $0.90 * *$ & $0.81 * *$ & $-0.85^{* *}$ & $0.84 * *$ & 0.38 & $-0.56^{*}$ & $-0.66^{*}$ & -0.38 & -0.40 & -0.31 & $-0.67 *$ & & & & & \\
\hline $\begin{array}{l}\mathbf{P d} \\
\end{array}$ & -0.53 & 0.27 & 0.54 & 0.20 & 0.10 & $0.87 * *$ & $0.60 *$ & -0.57 & $0.59 *$ & $0.82 * *$ & $0.88^{* *}$ & $-0.55^{*}$ & 0.04 & & & & \\
\hline Dia & $-0.56^{*}$ & 0.31 & 0.55 & 0.24 & 0.10 & $0.83^{* * *}$ & $0.59 *$ & $-0.58^{*}$ & 0.50 & $0.74 * *$ & $0.76^{* *}$ & $-0.57 *$ & 0.03 & $0.95 * *$ & & & \\
\hline Dino & -0.24 & 0.07 & 0.28 & 0.01 & 0.09 & 0.54 & 0.37 & -0.09 & 0.42 & $0.63^{*}$ & $0.74 * *$ & -0.27 & 0.01 & $0.67^{*}$ & 0.43 & & \\
\hline GA & 0.49 & -0.36 & -0.49 & 0.15 & -0.42 & -0.45 & -0.40 & 0.36 & -0.03 & -0.34 & -0.33 & 0.53 & -0.11 & -0.53 & -0.55 & -0.43 & \\
\hline$\overline{\text { BGA }}$ & $0.60^{*}$ & 0.54 & 0.11 & -0.39 & 0.23 & -0.06 & -0.54 & 0.04 & 0.09 & -0.23 & -0.34 & -0.09 & 0.38 & -0.36 & -0.52 & 0.05 & 0.29 \\
\hline
\end{tabular}

(Sal-salinity; Tur-turbidity; TSS-Total suspended solids; Pho-phospate; Nitra-nitrate; Nitri-nitrite; Sil-silicate; Am-ammonia; PD-plankton density; DIATdiatom, DINO-dinoflagellate, GA-green algae, BGA-blue green algae)

Table.5 Correlation matrix of various physico-chemical parameters with plankton groups in Naigaon

\begin{tabular}{|c|c|c|c|c|c|c|c|c|c|c|c|c|c|c|c|c|c|}
\hline & SST & $\mathrm{pH}$ & Sal & DO & BOD & Chla & Tur & TSS & Pho & Nitra & Nitri & Sil & $\mathrm{Am}$ & $\mathbf{P d}$ & DIAT & DINO & GA \\
\hline $\mathrm{pH}$ & 0.56 & & & & & & & & & & & & & & & & \\
\hline Sal & 0.50 & $0.92 * *$ & & & & & & & & & & & & & & & \\
\hline DO & $-0.56^{*}$ & $-0.81 * *$ & $-0.72 * *$ & & & & & & & & & & & & & & \\
\hline BOD & 0.54 & $0.82^{* *}$ & $0.73 * *$ & $-0.82 * *$ & & & & & & & & & & & & & \\
\hline Chla & -0.24 & 0.48 & 0.55 & -0.40 & 0.30 & & & & & & & & & & & & \\
\hline Tur & $-0.66^{*}$ & -0.06 & 0.07 & 0.22 & -0.25 & $0.71^{*}$ & & & & & & & & & & & \\
\hline TSS & -0.12 & $-0.80 * *$ & $-0.84 * *$ & $0.71 * *$ & $-0.73 * *$ & -0.82 & -0.34 & & & & & & & & & & \\
\hline Pho & $-0.59 *$ & -0.27 & -0.30 & 0.29 & -0.39 & $0.54^{*}$ & $0.68^{*}$ & -0.08 & & & & & & & & & \\
\hline Nitra & $-0.79 * *$ & $-0.62^{*}$ & $-0.64 *$ & $0.61 *$ & -0.61 & $0.60^{*}$ & $0.60^{*}$ & 0.25 & 0.89 & & & & & & & & \\
\hline Nitri & $-0.79 * *$ & $-0.68^{*}$ & $-0.59^{*}$ & $0.76^{* * *}$ & $-0.78 * *$ & $0.49 *$ & $0.66^{*}$ & 0.33 & 0.77 & $0.90^{* * *}$ & & & & & & & \\
\hline Sil & -0.35 & $-0.86^{* *}$ & $-0.94^{* *}$ & $0.77 * *$ & $-0.76^{* *}$ & $-0.70^{* * *}$ & -0.15 & $0.94 * *$ & 0.13 & 0.48 & 0.49 & & & & & & \\
\hline $\mathbf{A m}$ & $0.82 * *$ & $0.85^{* *}$ & $0.84 * *$ & $-0.77 * *$ & $0.78^{* *}$ & 0.18 & -0.35 & $-0.59 *$ & -0.55 & $-0.82 * *$ & $-0.80 * *$ & $-0.74 * *$ & & & & & \\
\hline$\overline{\text { PD }}$ & -0.43 & 0.32 & 0.38 & -0.10 & 0.10 & $0.90^{* *}$ & $0.84^{* *}$ & $-0.62 *$ & $0.54 *$ & $0.66 * *$ & $0.58^{*}$ & -0.46 & -0.03 & & & & \\
\hline DIAT & -0.49 & 0.29 & 0.33 & -0.07 & 0.12 & $0.88^{* * *}$ & $0.82 * *$ & $-0.61 *$ & 0.51 & 0.45 & 0.39 & -0.53 & -0.07 & $0.99 * *$ & & & \\
\hline DINO & -0.37 & 0.07 & 0.08 & 0.21 & -0.21 & 0.59 & $0.77^{* *}$ & -0.17 & 0.52 & 0.42 & 0.50 & -0.06 & -0.27 & $0.82 * *$ & $0.78 * *$ & & \\
\hline GA & $0.62 *$ & 0.01 & -0.07 & -0.09 & 0.08 & -0.50 & -0.36 & 0.30 & -0.52 & -0.49 & -0.38 & 0.13 & 0.40 & -0.51 & $-0.59 *$ & -0.31 & \\
\hline BGA & $0.55^{*}$ & 0.42 & $0.58^{*}$ & -0.48 & 0.15 & 0.55 & 0.31 & -0.49 & 0.12 & -0.20 & -0.08 & $-0.59 *$ & 0.43 & 0.33 & 0.21 & 0.18 & 0.20 \\
\hline
\end{tabular}

(Sal-salinity; Tur-turbidity; TSS-Total suspended solids; Pho-phospate; Nitra-nitrate; Nitri-nitrite; Sil-silicate; Am-ammonia; PD-plankton density; DIAT-

diatom, DINO-dinoflagellate, GA-green algae, BGA-blue green algae) 
Table.6 Canonical coefficients of physico-chemical parameters and plankton groups

\begin{tabular}{|l|c|c|}
\hline Variables & Axis 1 (74.1\%) & Axis 2 (24.09) \\
\hline Diatom & -0.092 & -0.008 \\
\hline Dinoflagelate & -0.143 & 0.025 \\
\hline Green algae & 0.267 & -0.222 \\
\hline Blue green algae & 0.298 & 0.162 \\
\hline Temperature & 0.340 & 0.900 \\
\hline Salinity & -0.091 & 0.859 \\
\hline pH & 0.026 & 0.829 \\
\hline DO & -0.227 & -0.850 \\
\hline BOD & -0.116 & 0.864 \\
\hline TSS & 0.354 & -0.803 \\
\hline Turbidity & 0.145 & -0.769 \\
\hline Chl-a & -0.788 & 0.589 \\
\hline Silicate & -0.001 & -0.137 \\
\hline Phosphate & -0.765 & 0.408 \\
\hline Nitrate & -0.900 & 0.335 \\
\hline Nitrite & -0.861 & 0.420 \\
\hline
\end{tabular}

The Concentration of total suspended solids (TSS) and turbidity demonstrated peak values during summer monsoon and low values during spring inter-monsoon. This can be viewed as a result of high terrestrial runoff and discharge of suspended particles into the creek ecosystems in summer monsoon which increases TSS and turbidity (Vinayachandran et al., 2002). While comparing the results of phytoplankton and TSS, a negative correlation was observed between TSS and the density of phytoplankton at both the stations (Table $4 \& 5$ ). The higher amount of TSS reduces the penetration of solar radiation, and this leads to the reduction in growth and abundance of phytoplankton (Rai and Rajashekar, 2014).

Phosphate, nitrate and nitrite were highest during winter monsoon and lowest during summer monsoon at both the stations (Table $3)$. Higher concentration of ammonia was recorded during spring inter-monsoon which got reduced significantly during summer monsoon season. Similar observations were reported for nitrate and ammonia by Vase et al., (2018) along Veraval coast. Nitrate concentrations were varying from $7.18 \mu \mathrm{M}$ $\mathrm{L}^{-1}$ to $28.4 \mu \mathrm{M} \mathrm{L}^{-1}$. A comparatively lower range of nitrate concentration $\left(2.2 \mu \mathrm{M} \mathrm{L}^{-1}-\right.$ $6.87 \mu \mathrm{M} \mathrm{L}^{-1}$ ) was described from the coastal waters of Veraval by Vase et al., (2018). The values of phosphate ranged from $1.39 \mu \mathrm{M} \mathrm{L}^{-1}$ to $6.97 \mu \mathrm{M} \mathrm{L}^{-1}$ in this study. However, Shahi et al., (2015) stated a wider range of phosphate concentration $\left(3.6-46.8 \mu \mathrm{M} \mathrm{L}^{-1}\right)$ in the coastal waters of Mumbai. Nitrate, nitrite and phosphate concentrations at both the stations showed significant positive correlations with plankton density and Chl-a (Table 4 and 5).

It has been mentioned that as long as the limiting nutrients such as nitrate and phosphate prevail in an aquatic ecosystem, the primary productivity and concentration of Chl-a will be very high (Lekshmi et al., 2018). This might have resulted in the positive correlation of Chl-a and plankton density with limiting nutrients such as phosphates, nitrates and nitrites. These results emphasize the essential nature of these nutrients for phytoplankton productivity in a tidal creek ecosystem. 
Silicate concentrations were the highest during the fall inter-monsoon season at both the stations. A significant negative correlation of silicate was noticed at both the creeks with diatom density and salinity (Table 4 and 5). The increased availability of silicate during the low saline phase indicates the incursion of fresh water from land runoff carrying silicates during monsoon and its accumulation during post-monsoon seasons as reported in earlier research reports (Kamalkanth et al., 2012). Moreover, the greater consumption of silicate by diatoms could be the possible reason for its low availability during winter monsoon. This observation was corroborated by the greater density of diatoms during winter monsoon.

The changes in the availability of nutrients in coastal ecosystems depends on their concentrations in the freshwater influx that mixes with seawater, land runoff, uptake of nutrients by phytoplankton, upwelling, chemical interactions and microbial decomposition (Satpathy et al., 2009; Shahi et al., 2015).

The availability of these nutrients in the coastal ecosystems regulates the growth and density of phytoplankton (Mochemadkar et al., 2013). Comparatively, the higher availability of limiting nutrients during winter monsoon might have enhanced the phytoplankton production at both the stations. Vase et al., (2018) reported that in the north eastern Arabian Sea, the higher concentrations of nutrients and higher productivity during the winter monsoon season is the end result of winter convective mixing and maturity of runoff nutrients during post-monsoon due to low current speed and low environmental perturbations. This mixing pattern, low environmental disturbance and the maturity of nutrients could be a major cause for the higher levels of limiting nutrients during winter monsoon in this study.
Canonical correspondence analysis (CCA) was carried out to determine the temporal variability in plankton groups in correspondence with the physico-chemical parameters of water. The canonical coefficients of environmental variables and plankton groups with the first two axes of CCA are given in Table 6. The results of CCA reveal that the seasonal variations in physico-chemical parameters are the major influencing factors for the distribution and abundance of phytoplankton. At both the stations (black dot representing Mahul and a red dot representing Naigaon), the abundance of diatoms and dinoflagellates was observed to be the highest during winter monsoon followed by fall inter-monsoon (Fig 4). At the higher levels of limiting nutrients during winter monsoon and fall inter-monsoon, the plankton density in terms of diatoms and dinoflagellates increased substantially. Therefore, a general consensus can be inferred from the CCA analysis that the major factors influencing plankton density of diatom and dinoflagellates are the concentrations of limiting nutrients such as nitrate, nitrite and phosphate.

The abundance of blue-green algae was observed during spring inter-monsoon at both the stations which coincided with high temperature and $\mathrm{pH}$. Thajuddin and Subramanian (2005) stated that compared to the other phytoplankton groups, blue-green algae require relatively high $\mathrm{pH}$ and temperature for ideal growth. Green algae were high at both the stations during summer monsoon when TSS and turbidity were high, and salinity and $\mathrm{pH}$ were low. It is reported that green algae tolerate extreme environmental changes compared to the other phytoplankton groups (Silva et al., 2004). Therefore, the abundance of green algae during summer monsoon is correlated to their tolerance to stressful conditions like high TSS and turbidity during the summer monsoon. 
From the CCA analysis, the major environmental factors which regulate the population of phytoplankton in various seasons were identified as nutrients, temperature, salinity and $\mathrm{pH}$.

The present study recapitulates the temporal fluctuations in physico-chemical parameters, phytoplankton abundance and diversity in Thane and Vasai tidal creeks of Maharashtra. Phytoplankton assemblages are highly dynamic depending primarily on the nutrient availability which is clearly explained by correlation analysis and CCA in the present study. The availability of nutrients in exact proportions and optimal environmental conditions generate high diversity and density of phytoplankton during winter monsoon. As phytoplankton form the base for coastal food webs, fish abundance and diversity are interlinked to plankton dynamics. Thus, the overall study gives a good outline of the seasonal dynamic relationship between phytoplankton and environmental parameters. Hence, the results from this study provide insight for further ecological assessment of the tidal creek coastal ecosystems and contribute towards ecosystem-based fisheries management in the region.

\section{Acknowledgements}

This study was carried out with scientific and technical support from Indian Council for Agricultural Research. Authors express heartfelt thanks to the Director, ICAR-CIFE and ICAR-CMFRI for facilities and support. We also convey our heartfelt thanks to all supporters of ICAR-CMFRI, Mumbai and CIFE, Mumbai for their kind cooperation.

\section{References}

Alheit, J., Mollmann, C., Dutz, J., Kornilovs, G., Loewe, P., Mohrholz, V. and Wasmund, N. 2005. Synchronous ecological regime shifts in the central
Baltic and the North Sea in the late 1980s. ICES J. Mari. Sci., 62(7): 1205-1215.

American Public Health Association, 2005. APHA (2005) Standard methods for the examination of water and wastewater.

Arthur R. Miller, 1972. Ecological Balance in Semi-Enclosed Seas, Envtl. Aff. L. Rev, 2(1): 191-204.

Chatterjee, A., Shankar, D., Shenoi, S. S. C., Reddy, G. V., Michael, G. S., Ravichandran, M., Gopalkrishna, V.V., Rao, E. R., Bhaskar, T.U. and Sanjeevan, V. N. 2012. A new atlas of temperature and salinity for the North Indian Ocean. J. Ear. Sys. Sci., 121(3):559-593.

Dalrymple, R. W., Zaitlin B. A. and Boyd, R. 1992. Estuarine facies models: conceptual basis and stratigraphic implications. J. Sediment. Petrol., 62: 1130-1146.

Devassy, V. P. and Goes, J. I. 1988. Phytoplankton community structure and succession in a tropical estuarine complex (central west coast of India). Est. Coastal Shelf Sci., 27(6): 671-685.

Gabriel, U.I., Benedict, O. O., and lrom, B. O. 2013. Plankton Distribution and Diversity in Tropical Earthen Fish Ponds. Env. and Nat. Res., 3. (3).

Hammer, O., Harper, D. A. T., and Ryan, P. D. 2001. PAST: Paleontological Statistics Software Package for Education and Data Analysis. Pal. Elec., 4(1): 9.

Harnstrom, K., Karunasagar, I. and Godhe, A. 2009. Phytoplankton species assemblages and their relationship to hydrographic factors a study at the old port in Mangalore, coastal Arabian Sea. IJMS. 38: 224-234.

Hulyal, S.B. and Kaliwal, B.B. 2009. Dynamics of phytoplankton in relation to physicochemical factors of Almatti reservoir of Bijapur District, Karnataka State. Env. Mon. and asses., 153(1-4): 45-59.

Jitendra, K., Benakappa, S., Gangadhara, G., Harsha, N., Lakshmipathi, M. T., Shivakumar, M., Anjanayappa, H. N., Somashekara, S. R., Naik, A. T. R. and Naik, A. S. K. 2016. Seasonal variations of oceanographic conditions and their 
influence on pelagic fisheries off Mangalore coast, Karnataka. J. Exp. Zoo., India, 19(2): 897-904.

Kadam, S. S. and Tiwari, L. R. (2011). Ecological study of Phytoplankton from Dahanu creek-west coast of India. Ind. J. Geo-marine sci., 40(4), 593-597.

Kamalkanth, S., Muniyan, M. and Christyponni, A. 2012. Seasonal variations in physicochemical parameters at Tranquebar Coastal Nagapattinam, Tamilnadu. India. Int. J. Environ. Biol, 2: 203-207.

Lekshmi, N. M., Sreekanth, G. B., Singh, N. P., Vennila, A., Kumar, R. R. and Pandey, P. K. 2018. Variations in phytoplankton assemblages in different aquaculture systems in coastal waters of Goa. IJMS. 48: 35-45.

Levinton, J. S. 2001. Marine biology. The Chemical and Physical Environment. Oxford University Press, (4).

Magurran, A. E. 2004. Meausuring Biological Diversity. Blackwell.

Mitbavkar, S. and Anil, A. C. 2008. Seasonal variations in the fouling diatom community structure from a monsoon influenced tropical estuary. Biofouling, 24: 415-426.

Mochemadkar, S., Gauns, M., Pratihary, A. K., Thorat, B. R., Roy, R., Pai, I. K. and Naqvi, S. W. A. 2013. Response of phytoplankton to nutrient enrichment with high growth rates in a tropical monsoonal estuary-Zuari estuary, India. IJMS. 42(3): 314-325.

Puthiya S. C., Poongothai, S. and Neelakantan, M. A. 2009. Impact of industrial pollution on the physico-chemical characteristics of sea water in Thoothukudi coastal area. Rasayan J. Chem., 2: 912-919.

Rai, S.V. and Rajashekhar, M. 2014. Seasonal assessment of hydrographic variables and phytoplankton community in the Arabian Sea waters of Kerala, southwest coast of India. Bra. J. Ocean., 62(4): 279-289.

Rajasekar, K. T., Rajkumar, M., Jun, S., Prabu, A. and Perumal, P. 2010. Seasonal variations of phytoplankton diversity in the Coleroon coastal waters, Southeast coast of India. Acta Oceanol. Sin., 29: 97108.

Roy, U., Biplab Kumar Shaha, Mazhabuddin, K. H., Fazlul Haque M. D. and Golam Sarower, M. D. 2010. Study on the diversity and seasonal variation of zooplankton in a brood pond Bangladesh. Mar. Res. Aqua., 1: 30-37.

Saifullah, A.S.M., Hena, M.K.A., Idris, M.H., Halimah, A.R., and Johan, I., 2014. Diversity of phytoplankton from mangrove Estuaries of Sarawak, Malaysia., World Appl. Sci. J., 31: 915924.

Saravanakumar A. M., Rajkumar J., Sesh, S. and Thivakaran G. A. 2008. Abundance and seasonal variations of zooplankton in the arid zone mangroves of Gulf of Kachchh-Gujarat, West coast of India, Pak. J. Biol. Sci., 10: 3525-3532.

Saravanakumar, A., Rajkumar, M., Thivakaran, G. A. and Serebiah, J. S., 2008. Abundance and seasonal variations of phytoplankton in the creek waters of western mangrove of Kachchh-Gujarat. J. env. Bio., 29(2): 271.

SAS Institute,SAS/STAT. 2012. User's Guide, Version 9.2, $4^{\text {th }}$ ed. Vol. 1. SAS Institute, Cary, NC,

Satpathy, K. K., Sahu, G., Mohanty, A. K., Prasad, M. V. R. and Panigrahy, R. C. 2009. Phytoplankton community structure and its variability during southwest to northeast monsoon transition in the coastal waters of Kalpakkam, east coast of India. Int. J. Oceans Oceanogr. 3 (1): 43-74.

Semeniuk, V. 1996. Coastal forms and Quaternary processes along the arid Pilbara coast of Northwestern Australia. Palaeogeography, Palaeoclimatology, Palaeoecology. 123: 49-84.

Shahi, N., Godhe, A., Mallik, S. K., Härnström, K. and Nayak, B. B. 2015. The relationship between variation of phytoplankton species composition and physico-chemical parameters in northern coastal waters of Mumbai, India. IJMS., 44(5): 673-684. 
Silva E. I. L. 2004. Phytoplankton characteristics, trophic evolution and nutrient dynamics in an urban eutrophic Lake: Kandy Lake in Sri Lanka, in: Restoration and management of tropical eutrophic lakes, edited by M. V. Reddy (Oxford and IBH Publishing): 219-260.

Sreekanth, G.B., Lekshmi, N.M. and Singh, N.P., 2017. Temporal Patterns in Fish Community Structure: Environmental Perturbations from a Well-Mixed Tropical Estuary. Proceedings of the National Academy of Sciences, India Section B: Biological Sciences, 87(1), pp.135-145.

Stowe, K. S. 1996. Exploring ocean science. Wiley.

Subrahmanyan R, 1959. Studies on the phytoplanktonof the west coast of India. Indian Acd. Sci.,50: 113-252.

Subramanyan, R. and Sen Gupta, R. 1965. Studies on the plankton of east coast of India. Proceedings of the Indiana Academy of Sciences, 56: 186-192.

Sukumaran, M., Muthukumaravel, K., and Sivakami, R. 2013.Seasonal variation in physico-chemical characteristics of Agniar Estuary, Southeast Coast of India, APJR. 2(7): 108-120.

Temkar, G. S., Azeez, P. A., Sikotaria, K. M., Brahmane, V. T., Metar, S. Y., Gangan, S. S., and Desai, A. Y. 2015. Correlation of phytoplankton density with certain hydrological parameters along the coastal waters of Veraval, Gujarat. J. Marine Bio. Assoc. Ind., 57(2): 2.

Thajuddin, N. and Subramanian, G. 2005. Cyanobacterial biodiversity and potential applications in biotechnology, Curr. Sci., 89: 47-57.

Thomas, S., Dineshbabu, A. P., Rajesh, K. M., Rohit, P., Nataraja, G. D. and Mishal, P. 2016. Environmental influence on the secondary productivity and fish abundance in coastal fishing grounds off Mangalore, south-eastern Arabian Sea. Ind. J. Fish., 61(3): 24-32.

Tiwari, A. and Chauhan. S. V. S. 2006. Seasonal phytoplanktonic diversity of Kitham Lake, Agra, J. Environ. Biol., 27: 35-38.

Vase, V. K., Dash, G., Sreenath, K. R., Temkar, G., Shailendra, R., Koya, K. M., Divu, D., Dash, S., Pradhan, R. K., Sukhdhane, K. S. and Jayasankar, J. 2018. Spatiotemporal variability of physico-chemical variables, chlorophyll a, and primary productivity in the northern Arabian Sea along India coast. Environ. Monit. Assess, 190: 148.

Vikas, M., Reddy, N. A., Rao, S. and Seelam, J. K. 2015. Classification of tidal inlets along the central west coast of India. Procedia Engineering, 116: 912-921.

Vinayachandran, P. N., Murty, V. S. N. and Ramesh Babu, V. 2002. Observations of barrier layer formation in the Bay of Bengal during summer monsoon. J. Geo. Res.: Oce. 107: 1-9.

Welch, P. S., 1948. Limnological Mehods (Blackston Co., Philadelphia): 381.

Yeragi, A. S. and Yeragi, S. G., 2003. Estimation of primary production of Acharaya creek of South Konkan, Maharashtra state. J. Aqua. Biol., 18(2): 33-36.

\section{How to cite this article:}

Ratheesh Kumar, R., A.P. Dineshbabu, A.K. Jaiswar, S.P. Shukla, N. Manju Lekshmi, G.B. Sreekanth, A.D. Nakhawa and Singh, V.V. 2018. Temporal Variations in Phytoplankton Assemblages at Dol Net Fishing Grounds of Major Tidal Creeks of Maharashtra, India. Int.J.Curr.Microbiol.App.Sci. 7(06): 465-480. doi: https://doi.org/10.20546/ijcmas.2018.706.052 